\title{
Clinical manifestations and severity of cow's milk anaphylaxis in children
}

\author{
Zahra Pourpak*, Pegah Teymourpour, Saeideh Barzegar, Raheleh Shokouhi, Mohammadreza Fazlollahi, \\ Mostafa Moin
}

From Food Allergy and Anaphylaxis Meeting 2011

Venice, Italy. 17-19 February 2011

\section{Background}

Anaphylaxis is a potentially fatal allergic reaction which is rapid in onset. Cow's milk is the most common allergen which can trigger anaphylaxis in Iranian children. The aim of this study is to describe the clinical features and severity of cow's milk anaphylaxis in children.

\section{Methods}

In this study all children $(<18$ years old $)$ with suspicious history of cow's milk anaphylaxis who had been referred to IAARI(Immunology,Asthma and Allergy Research Institute)during 2005(JAN) - 2010(SEP) were considered. A detailed questionnaire was fulfilled for each patient. A specific severity grading for anaphylaxis with five levels was also used. Skin Prick Test(SPT) with allergen extract(cow's milk) was performed at least 4-6 weeks after patient's last anaphylaxis attack. Cow's milk specific IgE and total IgE level were measured by Immunocap system.Patients with clear history and one positive laboratory test and patients with both positive laboratory tests(SPT and cow's milk specific IgE)were included.

\section{Results}

Among 49 patients ,29(59.2\%) were male and the rest were female.Patients' mean age at the time of first anaphylactic attack was $5.7 \pm 4.3$ months. The percentages of severity grades 1 - 5 were $2 \%, 6.1 \%, 18.4 \%, 69.4 \%, 4.1 \%$ o respectively. Most common clinical manifestations were in descending order as: Cutaneous $98 \%$ (urticaria,periorbital oedema,flushing), Respiratory91.8\%o(dyspnea,coughing,wheezing), Gastrointestinal 55.1\%o(nausea,vomiting, abdominal pain),Cardiovascular $46.9 \%$ and Neurologic $46.9 \%$.Twenty- four patients had positive SPT. Mean

Immunology,Asthma and Allergy Research Institute,Tehran University of Medical Sciences, Tehran, Islamic Republic of Iran total IgE level was $239.6 \pm 3.3(\mathrm{KU} / \mathrm{L})$ and mean cow's milk specific IgE was $19.28 \pm 27.2(\mathrm{KU} / \mathrm{L})$.

\section{Conclusions}

Since the patients'mean age at the time of first anaphylactic shock was $5.7 \pm 4.3$ months, we conclude that cow's milk anaphylaxis may happen very early in life. Most common manifestations are cutaneous and respiratory symptoms. Majority of attacks have been of moderate to relatively severe degree(grades 3 and 4) so equipping the general practitioners and pediatricians with enough knowledge about cow's milk anaphylaxis is needed.

Published: 12 August 2011

doi:10.1186/2045-7022-1-S1-P47

Cite this article as: Pourpak et al:: Clinical manifestations and severity of cow's milk anaphylaxis in children. Clinical and Translational Allergy 2011 1(Suppl 1):P47

\section{Submit your next manuscript to BioMed Central and take full advantage of: \\ - Convenient online submission \\ - Thorough peer review \\ - No space constraints or color figure charges \\ - Immediate publication on acceptance \\ - Inclusion in PubMed, CAS, Scopus and Google Scholar \\ - Research which is freely available for redistribution \\ Submit your manuscript at www.biomedcentral.com/submit}

C Biomed Central

(C) 2011 Pourpak et al; licensee BioMed Central Ltd. This is an open access article distributed under the terms of the Creative Commons Attribution License (http://creativecommons.org/licenses/by/2.0), which permits unrestricted use, distribution, and reproduction in any medium, provided the original work is properly cited. 